\title{
Combine effect of bio-fertilizer and poultry manure on growth, nutrients uptake and microbial population associated with sesame (Sesamumindicum L) inNorth-eastern Nigeria
}

\author{
Abdullahi, $\mathrm{R}^{1}$., Sheriff, H. $\mathrm{H}^{2}$. andLihan, $\mathrm{S}^{3}$. \\ ${ }^{I}$ Department of Soil Science, University of Maiduguri, Nigeria \\ ${ }^{2}$ Lake Chad Research Institute, Maiduguri, Nigeria \\ ${ }^{3}$ Department of Molecular Biology, Universiti Malaysia Sarawak
}

\begin{abstract}
The combine effect of bio-fertilizer (Azospirillum and arbuscularmycorrhiza fungi, AMF; Glomusmossea)and poultry manure (PM) on nutrients uptake, plant growth and soil microbial population associated with sesame under field condition was studied. The experiment comprised of four treatments; T1

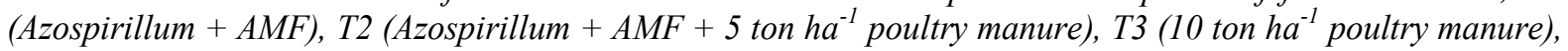
and TO (Control) laid out in randomized complete block design with three replications. Plant growth parameters viz., plant height, numbers of leaves/plant, numbers of branches/plant, leaf area, shoots and root dry biomass increased significantly due to the application of bio-fertilizer and poultry manure singly or in combination over control. Combined application of bio-fertilizer and poultry manure@ 5 ton ha ${ }^{-1}$ (bio-organic) significantly produced the plants with desirable growth parameters, nutrients content and uptakes for $N, P$, and $K$. Root colonization by AM fungi was recorded in inoculated and un-inoculated plants. Colonization \% ranges from $6 \%$ in control to $62.8 \%$ in Bio-organic. There was no significant difference in $\%$ root colonization of inoculated plants. Populations of Azospirillum and AM spores have increased in all treatments over the initial population prior to experiment in all treatments. Bio-organic recorded the highest Azospirillum population $\left(28.56 \times 10^{-6} \mathrm{CFU} \mathrm{g}^{-1}\right.$ soil) and $69.3 \mathrm{AM}$ spores $\mathrm{g}^{-1}$ soil and values were significantly higher to all the treatments. The overall findings of this research indicated that Bio-organic(bio-fertilizer and poultry manure @ 5 ton $\mathrm{ha}^{-1}$ ) produced plants with highest growth parameters, nutrients uptake, increased soil Azospirillum population, AM spore density and mycorrhization compared to exclusive application of bio-fertilizer or poultry manure@10 ton ha ${ }^{-1}$.Combination of bio-fertilizer with organic amendments could be recommended for successful production of sesame.
\end{abstract}

Key words: Bio-fertilizer, Poultry manure, Bio-organic, Plant growth, Nutrients uptake, Microbial population

\section{Introduction}

Sesame (Sesamumindicum L.)orbeniseedis a high value cash crop commonly cultivated by small holder farmers in Nigeria (Uwala, 1998; Alegbejo, 2003) for oil seed. The seed is nutritious: it contains 50-52\% oil, 19$25 \%$ protein and $16-18 \%$ carbohydrates (Uzoh, 1998; Weiss, 2000). Sesame is adapted to many soil types, drought- tolerant andgrows on poor fertile soil. Virtually, poor-resource holder farmers in Nigeria rarely apply fertilizer, but, best yields are obtained inproperly fertilized farms (PapariMoghaddamfard and Bahrani, 2005; Saeidi, 2008; Anon, 2006; Malik et al., 2003; Rao et al., 1994). Poor soil nutrients concentration especially, lowN, P and soil organic matter, coupled with unscientific method of cultivationare major constraints to its production in Nigeria. Yields are as low as $300 \mathrm{~kg} \mathrm{ha}^{-1}$ compared to $1,960 \mathrm{~kg} \mathrm{ha}^{-1}$ in Venezuela, $1,083 \mathrm{~kg} \mathrm{ha}^{-1}$ in Saudi Arabia (Abubakar et al., 1998), 1323 $\mathrm{kg} \mathrm{ha}^{-1}$ in Egypt and 825 $\mathrm{kg} \mathrm{ha}^{-1}$ in Ethiopia. Chemical fertilizers have been used for decades to increase crop yield. However, current trends in agriculture are focused on search for alternative to chemical fertilizer due to, huge cost of procurement, contamination of environment, and couple with improper application leading to the degradation of soil quality (Tilmanet al., 2002). Furthermore, the world demands for the production of quality food and in a most sustainable way maintaining soil biodiversity. Moreover, food produced organically fetch premium price in global market.

Bio-fertilizer (microbial inoculants) and organic amendments are cheap nutrient source that could serve as alternative to chemical fertilizers and improve crop production in low-input agriculture.Application of organic amendments, increases soil organic carbon and stimulate microbial activity which provides $\mathrm{N}$ and $\mathrm{P}$ to soil. Soil microorganisms on the other hand play a vital role in their ability to provide and recycle nutrient for plant growth (Weil and Magdoff, 2004). Their population and activities may not only reflect the quality of soil, but also reflect soil environmental conditions (Leaungvutiviroj et al., 2010). They are involved in interactions with plant roots, either symbiotically or as free-living, improving plant nutrients uptake, bolster crop production and improve soil quality (Wu et al., 2005; Okon and Itzisohn, 1995; Shah et al., 1992). Sesame production using organic amendments (Haruna and Abimiku, 2012;Ogbonna and Umar-Shaba, 2012) and chemical fertilizers 
(Umar et al., 2012; Shehu et al., 2010; Jakusko and Usman, 2013) have well been documented in Nigeria. Babajide et al. (2012) conducted pot experiment on bio-fertilizer (mycorrhizal inoculum) with organic and inorganic fertilizer on performance of sesame, in South-western region of Nigeria. However, there is little or no similar such work under field conditions. In this context, the combine effect of bio-fertilizer (Azospirillum and arbuscularmycorrhizal fungi, AMF)and poultry manure (PM) on nutrients uptake, plant growth and soil microbial population associated with sesame was studied under field conditions.

\section{Materials And Methods}

The experiment was conductedat 2007/2008 rainy season in the Teaching and Research Farm,Agricultural Technology, MohametLawan College of Agriculture, Maiduguri. Maiduguri lies in the semiarid region of northeastern Nigeria, $\left(11^{0} 15^{\prime} \mathrm{N}, 13^{0} 15^{\prime} \mathrm{E}\right.$ latitude). It is characterized by a short rainy season of 3-4 months (June - September) with an annual rainfall varying from $300 \mathrm{~mm}$ to $650 \mathrm{~mm}$ and a long term mean of $503 \mathrm{~mm}$ (Grema et al., 1995). The basic physico-chemical and biological properties of soil indicated that the soil was sandy loam (57\% sand, $23.4 \%$ silt and $19.7 \%$ clay), neutral ( $\mathrm{pH} 6.8)$, with $\mathrm{EC}$ value, $0.76 \mathrm{dS} \mathrm{m}^{-1}$. The soil had low nitrogen $(0.17 \%)$, organic carbon $(0.66 \%)$, available soil $\mathrm{P}\left(5.8 \mathrm{mg} \mathrm{kg}^{-1}\right)$, and exchangeable $\mathrm{K}(0.32$ $\mathrm{meq} / 100 \mathrm{~g}$ soil), with initialAzospirilliumbrasilensepopulation as few as $0.34 \times 10^{-5}$, andGlomusmossea(AMF) 5 spores/g soil.

The treatments were; T1 (Azospirillum + AMF), T2 (Azospirillum + AMF +5 ton ha $^{-1}$ poultry manure), T3 (10ton ha ${ }^{-1}$ poultry manure), and T0 (Control)laid out in randomized complete block design with three replications.Azospirilliumbrasilensewas isolated fromrhizosphere of maize,grown in nutrient broth for $48 \mathrm{~h}$ at $32^{\circ} \mathrm{C}$ in rotary shakerat the microbiological unit, Lake Chad Research Institute, Maiduguri. Number of Azospirillumin suspension was1 $\times 10^{9} \mathrm{cfuml}^{-1}$. Sand: soil mixture (1:2) containingextramatrical hyphae, spores, and root fragments of maize infected withGlomusmosseagrown for 3 months was used as soil inoculums for AMF. Azospirillum was applied as seed treatments and sprayed in soil 1 week after seedling emergence at 500 $\mathrm{ml} \mathrm{ha}^{-1}$ in 20001 of water. Viable sesame seeds (Ex-Sudan) were surface-sterilized andsoaked in Azospirillum culture for $1 \mathrm{~h}$ which was sown immediately while $10 \mathrm{~g}$ of AMF inoculums $(25$ spores g-1 soils with $\geq 80 \%$ root infection) was placed withinoculated seeds $3 \mathrm{~cm}$ below soil surface. The control plots were not inoculated

Experimental site was ploughed and harrowed. Composted poultry manure $(2.1 \% \mathrm{~N}, 1.3 \% \mathrm{P}$, and $1.5 \%$ $\mathrm{K}$ )was incorporatedto individual plot 1 week prior to seed sowingaccording to treatments. Six sterilized and viable seedswere sown at $75 \times 15 \mathrm{~cm}$ between and within rows in $2 \mathrm{~m} \times 2 \mathrm{~m}$ and later thinned to one. Inoculated and un-inoculated plots were separated by $2 \mathrm{~m}$ unplanted boarder. Seeds were sown on $16^{\text {th }} \mathrm{July}$ and plants harvested 6 weeks after sowing (WAS). At harvest, observations on plant height, number of branches/plant, leaf area, dry biomass of roots and shoots (constant weight after oven drying @ $65^{\circ} \mathrm{C}$ ), shoot content of $\mathrm{N}, \mathrm{P}$, and Kwere analyzed usingKjeldahl apparatus for nitrogen, while phosphorous and potassium were determined, by acetic acid extraction and measured with spectrophotometer and flame photometer as outlined by Johnson and Ulrich, (1959) and Knudsen et al., (1982) for P and K respectively. Azospirillum in rhizosphere were detected by most probable method, mycorrhizal root colonization assessed by rootclearing and staining (Philips and Hayman, 1970), and spore enumeration using wet-sieving and decanting(Gerdemann and Nicolson, 1963). Data were subjected to analysis of variance and differences among treatment means were separated using Fisher's least significant difference (LSD) at $\mathrm{P} \leq 0.05$.

\section{Plant growth response}

\section{Results}

Plant growth parameters viz., plant height, numbers of leaves/plant, numbers of branches/plant, leaf area, shoots and root dry biomass (Fig.1 \& Table 1) increased significantly due to the application of biofertilizer and poultry manure singly or in combination over control. Combined application of bio-fertilizer and poultry manure @ 5 ton ha ${ }^{-1}$ (bio-organic) significantly produced the plants with desirable growth parameters; plant height $(68.6 \mathrm{~cm})$, numbers of leaves/plant $(98.1)$, leaf area $\left(6.2 \mathrm{dm}^{-2}\right)$, shoot and root dry biomass $(6.18$, $\left.3.88 \mathrm{~g} \mathrm{plant}^{-1}\right)$, followed by bio-fertilizer and poultry manure (PM). 


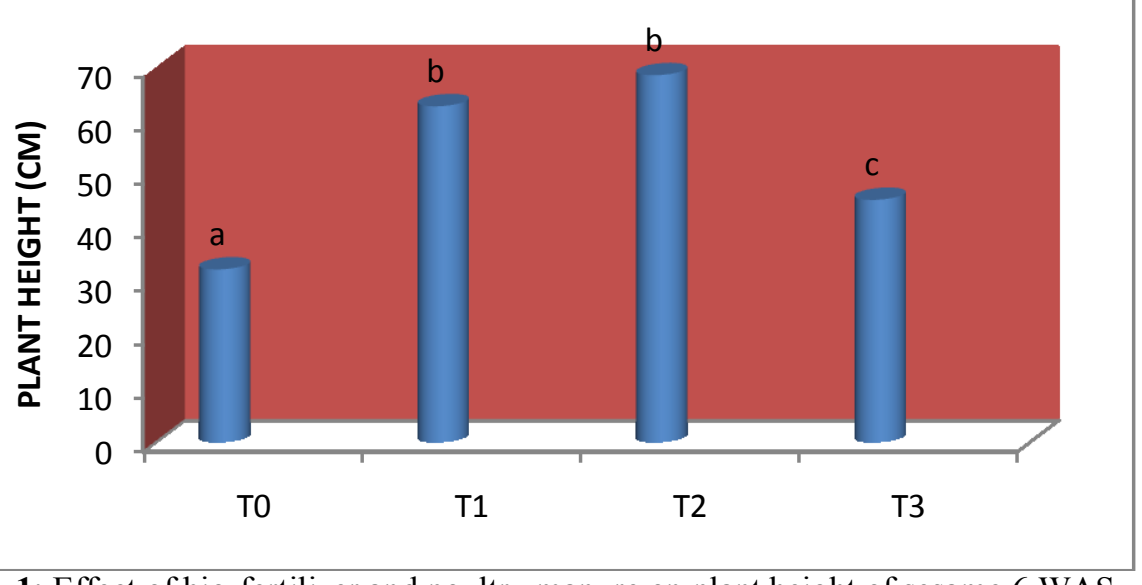

Fig. 1: Effect of bio-fertilizer and poultry manure on plant height of sesame 6 WAS

Legend: T0: (00) Absolute control, T1: (Bio-fertilizer), T2: (Bio-organic), T3: (PM).

Table 1: Growth response of sesame as affected by bio-fertilizer and poultry manure 6 WAS

\begin{tabular}{lllll} 
Treatments & $\begin{array}{l}\text { No. of branches } \\
\text { /plant }\end{array}$ & $\begin{array}{l}\text { No. of leaves } \\
\text { /plant }\end{array}$ & Leaf $\left(\mathbf{d m}^{-2}\right)$ & $\begin{array}{l}\text { Dry biomass (g/plant) } \\
\text { Shoot }\end{array}$ \\
\hline T0 Control & $4.5^{\mathrm{a}}$ & $42.3^{\mathrm{a}}$ & $3.8^{\mathrm{a}}$ & $4.45^{\mathrm{a}} 2.72^{\mathrm{a}}$ \\
\hline T1 Bio-fertilizer & $7.3^{\mathrm{b}}$ & $92.8^{\mathrm{b}}$ & $5.3^{\mathrm{b}}$ & $5.40^{\mathrm{b}} 3.70^{\mathrm{b}}$ \\
\hline T2 Bio-organic & $8.3^{\mathrm{b}}$ & $98.1^{\mathrm{b}}$ & $6.2^{\mathrm{c}}$ & $6.18^{\mathrm{c}} 3.88^{\mathrm{bc}}$ \\
T3 PM & $7.3^{\mathrm{b}}$ & $75.3^{\mathrm{c}}$ & $5.1^{\mathrm{b}}$ & $5.35^{\mathrm{b}} 3.62^{\mathrm{b}}$ \\
LSD (5\%) & 1.92 & 7.08 & 0.67 & 0.620 .22 \\
\hline
\end{tabular}

Values followed by the same superscript are not significantly $(\mathrm{P}<0.05)$ different according to Fischer's LSD test Nutrients concentration and uptake

Nutrients concentration and uptakes (Table 2) differs significantly amongst all the treatments. Plants inoculation with bio-fertilizer singly or in combination with PM increased nutrients contents and uptakes compared to the control. Bio-organic recorded the highest nutrients content and uptakes for $\mathrm{N}, \mathrm{P}$, and $\mathrm{K}$, and values were significantly higher to plants with single application of either bio-fertilizer of PM.

Table 2: Shoot nutrient contents and uptakes of N, P, and $\mathrm{K}$ as affected by bio-fertilizer and poultry manure on sesame 6 WAS

\begin{tabular}{|c|c|c|c|c|c|c|}
\hline \multirow[t]{2}{*}{ Treatments } & \multicolumn{3}{|c|}{ Concentration (\%) } & \multirow{2}{*}{$\begin{array}{l}\text { Uptakes } \\
\text { N }\end{array}$} & \multicolumn{2}{|c|}{$\left(\mathrm{kg} \mathrm{ha}^{-1}\right)$} \\
\hline & $\mathbf{N}$ & & $\mathbf{K}$ & & $\mathbf{P}$ & $\mathbf{K}$ \\
\hline T0 Control & $1.82^{\mathrm{a}}$ & $0.32^{\mathrm{a}}$ & $0.98^{\mathrm{a}}$ & $12.47^{\mathrm{a}}$ & $1.34^{\mathrm{a}}$ & $34.56^{\mathrm{a}}$ \\
\hline T1Biofertilizer & $3.54^{\mathrm{b}}$ & $0.51^{\mathrm{b}}$ & $1.43^{\mathrm{b}}$ & $36.38^{b}$ & $5.62^{b}$ & $50.41^{\mathrm{b}}$ \\
\hline T2Bio-organic & $3.93^{\mathrm{c}}$ & $0.56^{\mathrm{c}}$ & $1.62^{\mathrm{c}}$ & $40.96^{\mathrm{c}}$ & $6.79^{c}$ & $51.44^{\mathrm{b}}$ \\
\hline ТЗРМ & $3.20^{\mathrm{d}}$ & $0.46^{\mathrm{d}}$ & $1.30^{\mathrm{d}}$ & $31.42^{d}$ & $3.02^{d}$ & $45.47^{\mathrm{c}}$ \\
\hline LSD (5\%) & 0.11 & 0.02 & 0.09 & 3.76 & 0.54 & 3.98 \\
\hline
\end{tabular}

Values followed by the same superscript are not significantly $(\mathrm{P}<0.05)$ different according to Fischer's LSD test

\section{Root colonization}

Root colonization by AM fungi was recorded in inoculated and un-inoculated plants (Fig. 2). Colonization $\%$ ranges from $6 \%$ in control to $62.8 \%$ in Bio-organic. There was no significant difference in $\%$ root colonization of inoculated plants. However, un-inoculated plants treated with 10 ton ha ${ }^{-1} \mathrm{PM}_{\text {recorded }}$ significant colonization level of $11.8 \%$ over control $(6.0 \%)$. 


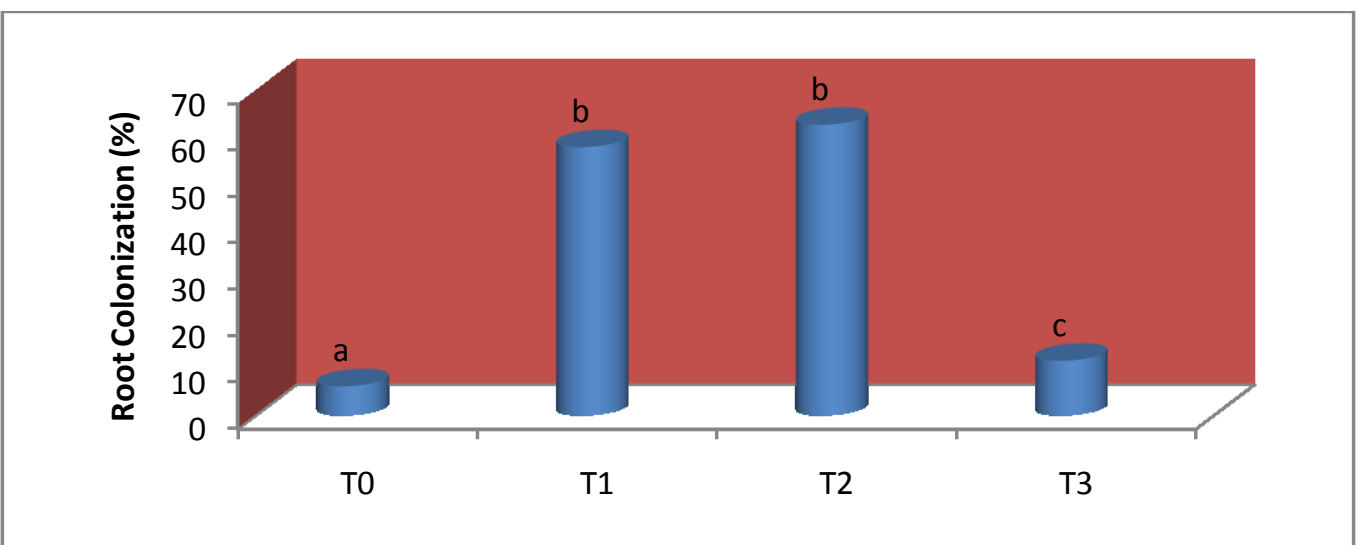

Fig. 2: Effect of bio-fertilizer and poultry manure on root colonization of sesame by AM fungi 6 WAS Legend: T0: (00) Absolute control, T1: (Bio-fertilizer), T2: (Bio-organic), T3: (PM).

\section{Azospirillum population and soil spore density of $A M F$}

Populations of Azospirillum and AM spores have increased in all treatments over the initial population prior to experiment. Bio-organic recorded the highest Azospirillum population $\left(28.56 \times 10^{-6} \mathrm{CFU} \mathrm{g}^{-1}\right.$ soil $)$ and 69.3 AM spores $\mathrm{g}^{-1}$ soil and values were significantly higher to all the treatments.

Table 3:Azospirillum population and AM spores as affected by different treatments 6 WAS of sesame

\begin{tabular}{lll}
\hline Treatments & $\begin{array}{l}\text { A.brasilenses } \\
\left(\mathbf{C F U} \times \mathbf{1 0}^{-6} \mathbf{g}^{-1} \text { soil) }\right.\end{array}$ & $\begin{array}{l}\text { G. mossea } \\
\text { (spores } \mathbf{~ g}^{-1} \text { soil) }\end{array}$ \\
\hline T0 Control & $4.50^{\mathrm{a}}$ & $8^{\mathrm{a}}$ \\
\hline T1 Bio-fertilizer & $23.12^{\mathrm{b}}$ & $62.5^{\mathrm{b}}$ \\
T2 Bio-organic & $28.56^{\mathrm{c}}$ & $69.3^{\mathrm{c}}$ \\
T3 PM & $13.16^{\mathrm{d}}$ & $10.3^{\mathrm{a}}$ \\
LSD (5\%) & 0.06 & 4.61 \\
\hline
\end{tabular}

Values followed by the same superscript are not significantly $(\mathrm{P}<0.05)$ different according to Fischer's LSD test

\section{Discussion}

Response in plant growth characteristic and nutrients uptakes in sesame plants was observed under inoculated plants compared to un-inoculated ones. Bio-organicproduced plants with highest growth parameters, nutrients uptakes, colonization $\%$ and increased microbial population followed by single application of biofertilizerthen PM@10 ton ha ${ }^{-1}$, while control recorded the least. Poor growth characteristics in control plants could be due to poor nutrients concentration and low soil organic matter in the study site. The positive effects of bio-fertilizer and poultry manure on plant growth as observed in this study have also been reported by some workers (Ahiabor and Hirata, 1994; Nwagburuka et al., 2012) using various organic amendments. They observed that inoculated plants grown with organic amendments produced plants with higher growth characteristics than un-inoculated ones. Several workers have reported similareffect ofbio-fertilizer on crop nutrients availability and yield (Sridevi and Ramakrishnan, 2010; Geeta et al., 2013). However, results were better obtained when bio-fertilizers were combined with organic amendments (Babajide et al., 2012; Worthington, 2001;Asaf et al., 2009). Positive growth response of inoculated plants could be due to provision of nutrients especially nitrogen and growth promoting hormones by Azospirillum and enhanced uptake of phosphorus and other nutrients due to mycorrhizal colonization (Bama and Ramakrishnan, 2010;Zaidi et al., 2004).Enhanced nutrients availability could also be attributed to the decomposition of organic manure or transforming of inorganic substances to available form by microorganisms. Increase in Azospirillum population, AM spore density and \%colonization could be motivated by the application of poultry manure, which became a source of carbon to the microbes thereby motivating their activities. Gianinazzi-Pearson (1982) reported that free living rhizobacteria such as AzotobacterandAzospirillum spp. can motivate spore production, bacterial community and colonization in rhizosphere of mycorrhizal plants. The result also confirms previous work on microbial properties in relationship to organic amendments (Groaker and Sreenivasa, 1994;Johansson et al., 2004; Crecchio et al., 2001). They concluded that addition of organic amendments could increase bacterial population and enhanced AMF colonization. 


\section{Conclusion}

The overall findings of this research indicated that combined effect of bio-fertilizer and poultry manure (a) 5 ton ha ${ }^{-1}$ produced plants with highest growth parameters and increased soil Azospirillumpopulation, AM spore density and mycorrhization compared to exclusive application of bio-fertilizer or poultry manure @ 10 ton $\mathrm{ha}^{-1}$. For successful production of sesame especially, on sandy soil with low nutrients concentration, and poor soil organic carbon, bio-organic fertilization could be recommended.

\section{References}

[1] Abubakar, S.S., Onyibe, J.E., \&Tologbonshien, E. B.(1998). The role of extension Research and information dissemination in enhancing beniseed production Production, marketing of resource poor farmers. Proceedings of the First Workshop on Beniseed held at the National Cereal Research Institute,Badegi, Nigeria, March 3rd-5 ${ }^{\text {th }}, 1998 . P p 86-9$.

[2] Ahiabor, B. D. and Hirata, H. (1994).Characteristics response of three tropical legumes to the inoculation of two species of VAM fungi and Andisol soils with different fertilities. Mycorrhiza, 4 (1) 365-375.

[3] Alegbejo.M.D. (2003). "Sesame: A Potential Industrial and Export Oilseed Crop in Nigeria". Journal of SustianableAgriculture . 23(1): 59-76.

[4] Anonymous.(2006). "Fertilizer Use by Crops in Zimbabwe”. FAO/UN: Rome, Italy.55pp.

[5] Assaf, T.A., Turk. M.A and Hameed .K.M. (2009). Impact of olive pomace wastes and fungicide treatment on indigenous arbuscularmycorrhizal fungi associated with chicken (Cicerarietinum L.) under field conditions .Australian Journal of Crop Science Southern Cross Journals 2009 3(1) :6-12 (2009). ISSN: 1835-2707.

[6] Babajide, P.A., Fagbola O. and Alamu L.O (2012). Influence of Biofertilizer-Fortified Organic and Inorganic Nitrogenous Fertilizers Performance of Sesame (Sesamumindicum Linn.) and Soil Properties Under Savanna Ecoregion . International Journal of Applied Agricultural and Apicultural Research IJAAAR (1) 108-116,108.

[7] BamaEzhil, M. and Ramakrishnan , K.(2010). Effects of Combined Innoculation of Azospirillum and AM fungi on the growth and Yield of Finger Millet (EleusinecoracanaGaetn ) Var.co 12 Journal of Experimental Sciences Vol.1,Issue 8, Pages 10-11 [2010]. ISSN: 2218-1768

[8] Crecchio, C., Curci, M., Mininni, R., Ricciuti, P. and Ruggiero, P. (2001).Short- termeffects of municipal solid waste compost amendments on soil carbon and nitrogen content, some enzyme activities and genetic diversity. Biology and Fertility of Soils, Vol. 34, No.5, pp 311-318.

[9] Flynn ,R.P.,C.W. Wood and J.T. Touchton.(1993).Nitrogen recovery from broiler litter in a wheat-millet production system Bioresource Technology 44(2): 165-173.

[10] Geeta. B., Patil 1,H,C., Lakshman, Romana. M., Mirdhe and Agadi.B.S.(2013).Effect of co- inoculation of AM fungi and two beneficial microorganisms on growth and nutrient uptake EleusiencoracanaGaertn. (Finger millet). Asian Journal of Plant Science and Research,2013,3(1):26-30.

[11] Gianinazzi-Pearson, T. P. (1982). Relationship between the critical concentration of nitrogen, phosphorus and potassium in seventeen different vegetable crops and duration of growth. J. Sci. Food Agric.; 31:1343-1353.

[12] Gerdemann, J.W. and Nicolson, T.H. (1963). Spores of mycorrhizalendogone species extract from soil by wet sieving and decanting. In Transactions of the British Mycological society 46:235-244.

[13] Grema, A.K., Mohammed, I. and Mshelia, I. (1995). Research highlights of the Collaborative Research Projection. North East Arid Zone Development Programme (NEAZDP) Gashua, Yobe State, Nigeria.

[14] Groaker S.B.N., Sreenivasa, M.N (1994). Effects of inoculation with Glomusfasciculatum in conjunctionwith different organic amendments on growth and grain yield of wheat (Triticumaestivum L). Microbial Res 149:419-423.

[15] Haruna, I.M andAbimiku. M.S .(2012). Yield of Sesame (Sesamumindicum L.) as Influenced by Organic Fertilizers in the Southern Guinea Savanna of Nigeria. Sustainable Agriculture Research Vol.1, No. 1; February 2012.

[16] Jakusko, B.B. and Usman .B.D.(2013). Effects of npk fertilizer and plant population density on productivity of sesame (Sesamumindicum L.) Research Journal of Agricultural and Environmental Management Vol.2 (5).pp. 121-126.

[17] Johansson ,J., Paul, L. R., Finlay, R.D.(2004). Microbial interactions in the micorrhizosphere and their significance for sustainable agriculture. FEMS Microbiology Ecology. Vol.48,No. 1.p.1-13.2004.

[18] Johnson,C. M. and Ulrich, A. (1959).Analytical methods for for use in plant analysis, Bulletin 766. University California, Agricultural Experiment Station, Berkeley, pp:26-78.

[19] Knudsen, D., Peterson, G. A, Pratt, P.F.(1982) Lithium, sodium and potassium .In: Page AL, Millar RH, Keeney DR (eds) Methods of soil analysis .Part 2.American Society of Agronomy, Madison, WI,pp225-246.

[20] Leaungvutiviroj, C., Piriyaprin, S., Limtong, P. and Sasaki , K.(2012) Relationships between soil microorganisms and nutrient contents of Vetiverizizanioides (L.) Nash and Vetiverianemoralis (A.) Camus in some problem soils from Thailand. Pplied Soil Ecology, 46,95-102. Lynch J.M., The rhizosphere, John Wiley, New York, USA,1990.

[21] Malik , A. M. M. F. Salem, M. A. Cheema, and S. Ahmed .2003. "Influence of Nitrogen Levels on Productivity of Sesame (Sesamumindicum L) under Varying Planting Patterns', International Journal of Agriculture and Biology.4:490-492.

[22] Nwangburuka, C. C., Olawuyi, O.J., Oyekale, K., Ogunwenmo, K.O., Denton, O.A. and Nwanko, E.(2012). Growth and yield response of Corchorusolitorius in the treatment of Arbuscularmychorrhizae (AM),Poultry manure (PM), Combination of AM-PM and inorganic Fertilizer (NPK). Advances in Applied Science Research,2012, 3(3):1466-1471.

[23] Ogbonno, P. E. and Umar-Shaba, Y, G. (2012). Influence of poultry manure application on growth and yield performance of accessions of sesame (Sesamumindicum L.) in a derived savannah transition zone of South eastern Nigeria. Africa Journal of Agricultural Research Vol.7(30), pp.4223-4235.

[24] Okon,Y. and R. Itzisohn ,1995.the development of Azospirillum as a commercial inoculant for improving crop yields. Biotechnol .Adv., 13:414-424.

[25] PapariMoghaddamfard A, Bahrani MJ. 2005. Effect of nitrogen fertilizer rates and plant density on some agronomic characteristic , seed yield and protein percentage in two sesame cultivars (In Persian with English abstract).Iranian J Agri Res 36(1): 129-135.

[26] Phillips, J.M., and Hayman, D.S., (1970). Improved procedures for clearing roots and staining parasitic and vesiculararbuscularmycorrhizal fungi for rapid assessment of infection.Trans. Br. Mycol. Soc., 55:158-161.

[27] Rao, V. P., Raikhelkar, S. V. and Sondge, V. D. (1994).Effect of irrigation and fertilization on yield and its components in sesame (Sesamumindicum L.). Indian J. Agric. Sci., 64:93-100. 
[28] Saeidi G. H. A. (2008). Effect of some macro and micronutrients on seed yield and otheragronomic traits of sesame in Insfaha (In Persian with English abstract). Iranian J Agricand Natural Resources Sci. and Technol 12 (45): 319-390.

[29] Shah S, Karkhanis V, Desai A (1992) Isolation and characterization of siderophore, with antimicrobial activity, from AzospirillumlipoferumM.Current Microbiology 25:347-351.

[30] Shehu, H.E., Kwari,J.D. and Sandabe, M.K. (2010). Effects of N,P. and K fertilizers on yield content and uptake of N.P. and K by sesame (sesamumindicum).Int. J. Agric. Biol., 12:845-850.

[31] Sridevi ,S.andRamakrishnan, K.(2010).Effects of combined inoculation of am fungi and Azospirillum 0n the growth and yield of onion (Allium cepa L.). Journal of Phytology Phytophysiology, 2(1): 88-90 ISSN:2075-6240.

[32] Tilman, D., Cassman, K.G., Matson, P.A., Naylor, R., and Polasky, S. (2002). Agricultural sustainability and intensive production practices. Nature 418, 671-677.

[33] Umar,U.A., Mahmud, M., Abubakar, I.U., Babaji,B. A and Idris, U.D (2012).Performance of sesame (Sesamumindicun L) Varieties as Influenced by Nitrogen Fertilizer Level and Intra Row Spacing.The Pacific Journal of Science and Technology Volume 13. Number2. November 2012 (Fall)

[34] Uwala AC (1998) Evaluation of Chlorithalonil. Benlate and Agrimycin 500 on the control of leafspot disease and their effects on the yield of sesame in Southern Guinea Savannah. In: L.D.Busari, A.A. Idowu and S.M. Misari (eds). Proc. ${ }^{\text {st }}$ National

[35] Uzoh, J .O (1998) Beniseed-a neglected oil wealth of Nigeria . In: L.D. Busari, A.A. IdowuandS.M.Misari (eds). Proc. ${ }^{\text {st }}$ National Workshop on Beniseed.3-5 March 1998, NVRI, Badeggi, pp.1-2.

[36] Weil, R.R., Magdoff.F. (2004).Significance of soil organic matter to soil quality and health. In: F. Magdoff, F., Weil, R.R.(Eds.) Soil organic matter in sustainable agriculture .CRC Press.Boca Raton .FL. pp.1-43.

[37] Weiss, E. A. (2000). Oilseed crops. Blackwell Science Ltd., p. 142.

[38] Worthington, V. (2001). Nutritional quality of organic versus conventional fruits, vegetables, and grains. Journals of Alternative and Complementary Medicine. 7: 161-73.

[39] Zaidi.A.,M.s. Khan and M. Aamil. (2004). Bioassociative effect of rhizosphericmicrorganismsongrowyh, yield and nutrient uptake of greengram. J.Plant Nutr.27:599-610. 